\title{
MENINGKATKAN MINAT WIRAUSAHA SISWA SMK UNTUK MENGURANGI KEMISKINAN DENGAN PERCEIVED DESIRABILITY DAN FEASIBILITY
}

\author{
Gallant Asunka \\ Universitas Pendidikan Indonesia \\ gallant.asunka@student.upi.edu \\ Bambang Widjajanta \\ Universitas Pendidikan Indonesia \\ Bambangwidjajanta@upi.edu \\ Lisnawati \\ Universitas Pendidikan Indonesia \\ Lisnawati@upi.edu
}

\begin{abstract}
ABSTRAK
Tujuan - Seberapa besar pengaruh perceived desirability dan feasibility terhadap minat berwirausaha siswa SMK.

Desain/metodologi/Pendekatan - Jenis penelitian yang digunakan adalah deskriptif, verifikatif, dengan jumlah sampel sebanyak 100 siswa. Teknik analisa data yang digunakan adalah regresi linear berganda.

Temuan - Dari penelitian terhadap pengujian hipotesis dapat diketahui bahwa perceived desirability dan feasibility memiliki pengaruh yang positif/katergori besar, baik terhadap minat berwirausaha siswa SMK..

Orisinalitas - Perbedaan ditemukan dalam objek penelitian, periode penelitian, alat ukur dan hasil penelitian. Penulis juga menambahkan teori dari jurnal asing dan buku asing
\end{abstract}

Kata kunci: perceived desirability, perceived feasibility, minat berwirausaha, rendahnya minat Tipe artikel: Reseach Paper berwirausaha, pengangguran SMK.

\section{PENDAHULUAN}

Kesadaran masyarakat Indonesia akan pentingnya wirausaha masih sangat rendah jika dibandingkan dengan negara-negara lain di dunia. Padahal pertumbuhan dan pembangunan ekonomi akan lebih berhasil jika didukung oleh para entrepreneur. Penelitian yang dilakukan Kritikos (2014) menyatakan wirausaha akan mendorong pertumbuhan ekonomi, meningkatkan daya saing, membuka lapangan pekerjaan baru, dan meningkatkan produktivitas. Hal ini diperkuat oleh Smith (2010) yang melakukan penelitian di 77 negara menegaskan jika tingkat kewirausahaan di suatu negara sangat berpengaruh positif terhadap tingkat pertumbuhan ekonomi di negara tersebut. Indonesia dapat menjadi negara maju jika memiliki tingkat aktivitas wirausaha yang tinggi, tetapi menurut (Badan pusat statistik, 2014) jumlah wirausaha di Indonesia pada tahun 2014 hanya mencapai 1,65 persen. Jumlah tersebut sangat rendah jika dibandingkan dengan negara-negara maju di dunia. Salah satu faktor rendahnya jumlah wirausaha di Indonesia terjadi karena kurangnya minat lulusan sekolah menengah dan perguruan tinggi untuk berwirausaha, mereka lebih memilih untuk menjadi pegawai swasta atau Pegawai Negeri Sipil (PNS) dari pada menjadi seorang entrepreneur (Wahyono:2013). Berbeda dengan Indonesia, di negara maju seperti Amerika Serikat menurut National Association of Colleges and Employers (2013) jumlah masyarakat yang mau menjadi seorang entrepreneur sebesar 36 persen, sedangkan yang memilih bekerja di sektor pemerintahan hanya 6 persen. Rendahnya minat berwirausaha tidak hanya terjadi di Indonesia, tetapi terjadi di negara lain. Beberapa penelitian yang dilakukan terhadap siswa-siswi di beberapa negara berkembang, mengemukakan jika mayoritas siswa-siswi tersebut setelah lulus, cenderung memilih untuk mencari kerja dari pada menjadi seorang entrepreneur (Achchuthan dan Nimalathasan, 2012; Anne Støren, 2014; Boyd, Fietze, dan Philipsen, 2015; Fatoki, 2010; Smith, 2010) Tingkat Pengangguran Terbuka (TPT) lulusan SMK pada Agustus 2014 berjumlah $11.24 \%$ dan menempati posisi teratas dari total pengangguran di Indonesia dari tahun ke tahun. Hal ini mengindikasikan jika orientasi lulusan SMK masih mencari lapangan pekerjaan bukan membuka lapangan kerja baru. Fenomena ini akan berdampak pada banyaknya jumlah pengangguran di usia muda. Banyaknya pengangguran di usia muda harus segera ditemukan solusinya karena pengangguran di usia mudah lebih rentan mengalami kemiskinan, 
kehilangan motivasi, masalah mental, dan depresi (Nedeljkovic, 2014).

Salah satu upaya untuk menciptakan entrepreneur baru pada lulusan SMK, yaitu dengan menumbuhkan minat dan kesadaran lulusan SMK untuk berwirausaha, karena menurut theory planned behavior yang dikemukakan Ajzen (1991) bahwa minat berwirausaha merupakan prediktor terbaik yang mempengaruhi perilaku berwirausaha, jadi ketika minat berwirausaha rendah maka perilaku berwirausaha akan rendah, ini artinya tidak akan tercipta wirausaha dan lapangan kerja baru.

Dua teori utama yang digunakan sebagai dasar oleh para peneliti untuk meneliti tentang minat berwirausaha sebagai prediktor dari perilaku berwirausaha, yaitu: The Entrepreneurial Event Theory Shapero dan Sokol (1982) dan The Theory of Planed Behavior (Ajzen, 1991) Krueger, Reilly, dan Carsrud (2000) melakukan penelitian dengan membandingkan antara Theory Entrepreneurial Event dan Theory of Planned Behavior. Hasilnya menyimpulkan bahwa kedua model penelitian tersebut memiliki kemampuan memprediksi minat berwirausaha, di mana Theory Entrepreneurial Event memberikan kekuatan hubungan lebih besar.

Krueger et al., (2000) Model Shapero dan Sokol dikembangkan atas dasar tiga elemen, yaitu perceived desirability, perceived feasibility, dan propensity to act. Model tersebut menjelaskan bahwa terjadinya minat kewirausahaan membutuhkan kredibilitas perilaku dan kecenderungan untuk bertindak. Perilaku dikatakan kredibel apabila perilaku tersebut menarik (perceptions of desirability) dan mampu untuk dilaksanakan (perceptions of feasibility). Persepsi keinginan adalah persepsi tentang seberapa atraktif gagasan yang ditemukan untuk memulai berwirausaha (Almqvist dan Björnberg, 2010). Sedangkan persepsi kelayakan adalah persepsi tentang kemudahan atau kesulitan untuk memulai berwirausaha (Solesvik, 2012) Darmanto, (2013) mengemukakan bahwa Perceived Desirability, Perceived Feasibility dan Propensity to Act berpengaruh positif dan signifikan terhadap minat berwirausaha. Penelitian yang dilakukan Ngugi, Gakure, Waithaka, dan Kiwara, (2012) menyatatakan bahwa tiga variabel di dalam Theory of Entrepreneurial Event berpengaruh signifikan terhadap minat berwirausaha. Penelitian yang dilakukan Dissanayake (2014) membuktikan bahwa Perceived Desirability dan Perceived Feasibility sangat berpengaruh positif terhadap minat berwirausaha. Sedangkan penelitian yang dilakukan oleh Weerakoon dan Hhaj (2014) menyatakan semakin tinggi Perceived Desirability dan Perceived Feasibility maka semakin tinggi kemungkinan munculnya minat berwirausaha.

\section{KAJIAN PUSTAKA}

Kewirausahaan adalah sebuah proses yang mengintegrasikan peluang (opportunity), sumber daya (resources) dan orang (wirausahawan). (Timmons dan Spinelli, 2009). Pengidentifikasian peluang adalah langkah awal dalam berwirausaha dan proses ini dikenal dengan minat berwirausaha (Wang, Lu, dan Millington, 2011). Individu mempunyai intentions yang kuat untuk mempunyai usaha ketika mereka merasa usaha tersebut ada kemungkinan untuk dikerjakan (feasibility) dan ada keinginan untuk melaksanakan kegiatan usaha tersebut (desirable) (Hisrich et al., 2008).

Minat berwirusaha akan timbul ketika seseorang memiliki ketertarikan dan merasa mampu untuk melakukan usaha. Perceived desirability dan feasibility jika digabungan, maka akan memicu minat berwirausaha seorang individu. (Darmanto, 2013; Fitzsimmons dan Douglas, 2011; Giagtzi, 2013; Guerrero, Rialp, dan Urbano, 2008; Mair \& Noboa, 2005; Shapero dan Sokol, 1982). Perceived desirability adalah persepsi tentang seberapa atraktif gagasan yang ditemukan seseorang untuk memulai berwirausaha (Almqvist dan Björnberg, 2010; Drennan dan Kennedy, 2004; Mair dan Noboa, 2005; Summers, 2000). Perceived desirability mengacu pada sejauh mana seseorang merasa ingin dan merasakan daya tarik terhadap perilaku terntentu, seperti menjadi seorang entrepreneur. Tanpa daya tarik seseorang tidak akan memiliki minat untuk melakukan suatu tindakan, dengan demikian daya tarik sangat diperlukan untuk menumbuhkan minat berwirausaha seseorang.

Persepsi keinginan dipengaruhi oleh kekuatan-kekuatan sosial, terutama dari keluarga, teman, kelompok sebaya, dan mentor mempengaruhi pembentukan persepsi keinginan yang akan membantu menentukan minat berwirausaha seseorang (Carsrud \& Brännback, 2009; Shapero \& Sokol, 1982). Sedangkan menurut Krueger (1993); Scherer, (1989); dan Summers (2000) dua faktor utama yang mempengaruhi pembentukan dari persepsi keinginan. Pertama, kualitas dan kuantitas luasnya pengalaman dimasa lalu, yang mana evaluasi dari kualitas dan kuantitas dari pengalaman kewirausahaan di masa lalu, akan menyediakan informasi mengenai perilaku keinginan berwirausaha dari keterlibatan langsung ataupun observasi. Kedua, dukungan sosial, yaitu apa yang orang lain pikirkan sangat berpengaruh terhadap perilaku seorang individu, memberikan persuasi verbal yang akan mendorong entrepreneur merasakan ketertarikan 
atau tidak untuk memulai suatu usaha. Individu dengan pengalaman berwirausaha yang baik, terutama berkualitas akan membentuk persepsi keinginan dan kelayakan yang aktif tentang aktivitas berwirausaha. Jadi menurut Shapero dan Sokol, dukungan sosial dan pegalaman berwirusaha seseorang dimasa lalu, akan mempengaruhi persepsi keinginan seseorang.

Adapun faktor-faktor yang mempengaruhi minat berwirausaha (Ratsimanetrimanana, 2014): attitude toward entrepreneurship, kebutuhan akan prestasi, dan high level of energy.

Menurut Summers (2000) Minat berwirausaha disebabkan adanya kejadian yang memicu (trigger events), persepsi keinginan (perceived desirability), kecenderungan untuk berperilaku proaktif (propensity for proactive behavior), dan kepercayaan individu pada kemampuannya untuk berhasil (self efficacy assessment). Sedangkan Menurut model Theory of Entrepreneurial Event Shapero dan Sokol (1982) menjelaskan bahwa terjadinya minat kewirausahaan membutuhkan kredibilitas perilaku dan kecenderungan untuk bertindak. Perilaku dikatakan kredibel apabila perilaku tersebut menarik (perceptions of desirability) dan mampu untuk dilaksanakan (perceptions of feasibility).

Persepsi keinginan adalah sejauh mana seorang individu secara positif atau negatif menilai tindakannya (Weber, 2012). Sedangkan menurut Summers, (2000) Persepsi keinginan adalah ukuran sikap seseorang untuk memulai bisnis, dengan kata lain rasa ketertarikan seseorang terhadap kewirausahaan dapat dijadikan prediktor untuk melihat perilaku berwirausaha seseorang. Dua faktor utama yang mempengaruhi pembentukan dari persepsi keinginan. Pertama, kualitas dan kuantitas luasnya pengalaman dimasa lalu, yang mana evaluasi dari kualitas dan kuantitas dari pengalaman kewirausahaan di masa lalu, akan menyediakan informasi mengenai perilaku keinginan berwirausaha dari keterlibatan langsung ataupun observasi. Kedua, dukungan sosial, yaitu apa yang orang lain pikirkan sangat berpengaruh terhadap perilaku seorang individu, memberikan persuasi verbal yang akan mendorong entrepreneur merasakan ketertarikan atau tidak untuk memulai suatu usaha (Summers, 2000)

Perceived feasibility adalah derajat kepercayaan dimana seseorang memandang dirinya mempunyai kemampuan untuk mengumpulkan sumber daya-sumber daya (manusia, sosial, finansial) untuk membangun usaha Segal, Borgia, dan Schoenfeld, (2005). Hal ini hampir serupa dengan pernyataan Summers (2000) Tingkat dimana seseorang merasa dia mampu untuk memulai bisnis. Dengan demikian Jika seseorang memutuskan untuk membangun usaha atau bisnis baru, maka hal itu merupakan hasil dari persepsi kelayakan. Sebab ia mampu berpikir tentang hasil tersebut memang layak atau pantas diraihnya. Sebaliknya, ia tidak akan memutuskan untuk memulai suatu bisnis baru seandainya ia tidak dapat menentukan hasil yang dicapai dan apakah hasil tersebut memang diinginkan dan layak untuk diperoleh. Krueger dan Carsrud (1993), menyatakan bahwa persepsi kelayakan adalah keyakinan individu akan kemampuannya untuk memulai bisnis baru. keyakinan ini berdasarkan beberapa aspek seperti, pengetahuan, keterampilan, dan emosi untuk menjadi seorang pengusaha. Dengan demikian sebelum pengetahuan, keterampilan dan emosi seseorang tentang wirausaha, akan berpengaruh terhadap keyakinannya apakah ia mampu atau tidak untuk menjadi seorang pengusaha.

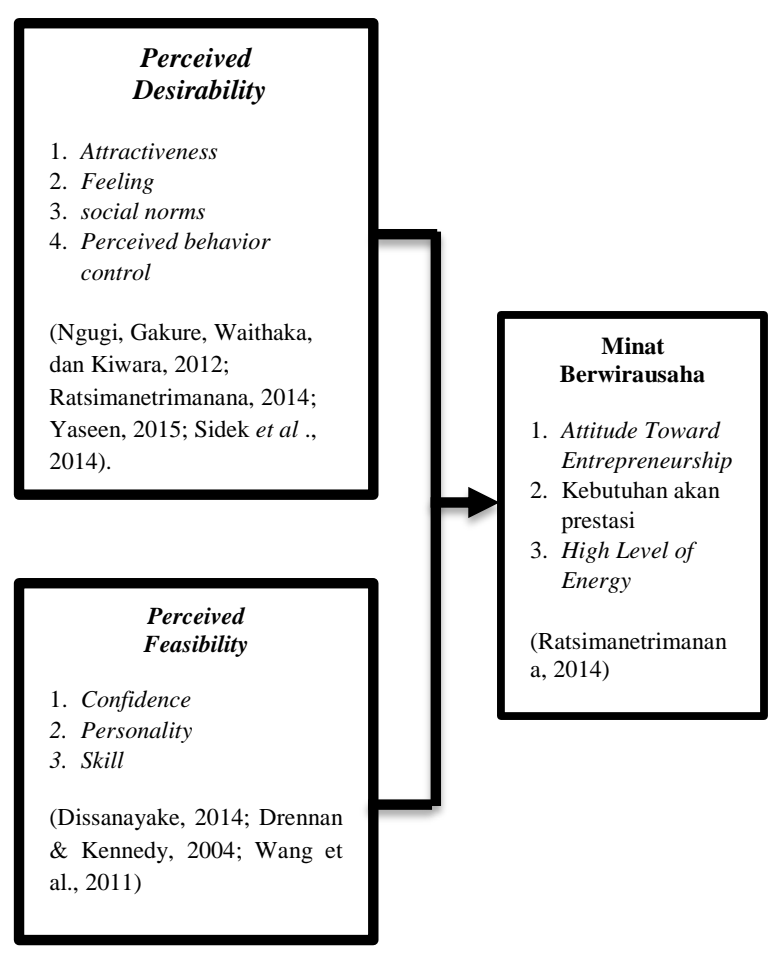

Gambar 1 Paradigma Penelitian

\section{METODE PENELITIAN}

Penelitian ini dilakukan untuk mengetahui pengaruh perceived desiability dan feasibility terhadap minat berwirausaha pada siswa SMK. Objek/unit analisis pada penelitian ini yaitu siswa SMK di Kota Cimahi. Penelitian ini dilakukan pada kurun waktu kurang dari satu tahun, sehingga teknik pengumpulan data yang digunakan pada penelitian ini adalah crosssectional method. Teknik yang digunakan dalam penelitian ini adalah teknik regresi liniear berganda dengan jumlah sampel sebanyak 100 
responden. Teknik pengumpulan data yang digunakan adalah studi kepustakaan, studi lapangan dengan penyebaran kuesioner, dan studi literatur. Sedangkan teknik analisis data yang dilakukan adalah analisis deskriptif dan verifikatif. Analisis data verifikatif menggunakan analisis jalur dengan bantuan software SPSS 21..0 for windows.

\section{HASIL PENELITIAN DAN PEMBAHASAN}

Pengujian hipotesis penelitian ini dilakukan untuk mengetahui besarnya pengaruh pengaruh perceived desiability dan feasibility terhadap minat berwirausaha pada siswa SMK. Berdasarkan hasil penelitian diperoleh besaran koefisien jalur dari setiap hipotesis seperti pada gambar berikut.

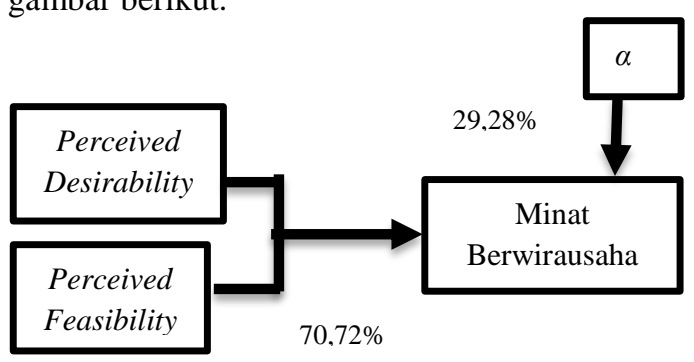

Gambar 2 Diagram Jalur Pengujian Hipotesis

Berdasarkan diagram tersebut, menyatakan perceived desirability dan feasibility berpengaruh positif terhadap minat berwirausaha adalah sebesar $70,72 \%$. Hal ini menunjukkan bahwa status perceived desirability dan feasibility secara simultan berpengaruh terhadap minat berwirausaha pada siswa SMK. Sedangkan $29,28 \%$ dipengaruhi oleh variabel yang tidak diteliti pada penelitian ini.

Berdasarkan hasil penelitian, hal tersebut sesuai dengan penelitian yang dilakukan Shapero dan Sokol (1982) menjelaskan bahwa terjadinya minat kewirausahaan membutuhkan kredibilitas perilaku dan kecenderungan untuk bertindak. Perilaku dikatakan kredibel apabila perilaku tersebut menarik (perceptions of desirability) dan mampu untuk dilaksanakan (perceptions of feasibility). Hisrich et al., (2008) Individu mempunyai intentions yang kuat untuk mempunyai usaha ketika mereka merasa usaha tersebut ada kemungkinan untuk dikerjakan (feasibility) dan ada keinginan untuk melaksanakan kegiatan usaha tersebut (desirable). Berdasarkan uraian tersebut, bila perceived desirability dan feasibility diterapkan dengan baik maka akan timbul ketertarikan dan rasa percaya diri untuk memulai berwirausaha, sehingga minat berwirausaha siswa meningkat dan dapat menjadikan siswa sebagai wirausahawan baru yang trampil dan berwawasan luas.

\section{DAFTAR PUSTAKA}

Achchuthan, S., \& Nimalathasan, B. (2012). Level of entrepreneurial intention of the management undergraduates in the university of jaffna, Sri Lanka: Scholars and undergraduates perspective. ACADEMICIA: An International Multidisciplinary Research Journal, 2(10), 24-42. Retrieved from http://www.indianjournals.com/ijor.aspx?ta rget=ijor:aca \&volume $=2 \&$ issue $=10 \&$ article $=002$

Ajzen, I. (1991). The Theory of Planned Behavior. Organisation Behavior and Human Decision Process, 50(2), 179-211. http://doi.org/10.1016/07495978(91)90020-T

Almqvist, A. S., \& Björnberg, A. (2010). Selecting Self-Employment OF ECONOMICS.

Anne Støren, L. (2014). Entrepreneurship in higher education. Education + Training, 56(8/9), 795-813. http://doi.org/10.1108/ET-06-2014-0070

Badan pusat statistik. (2014). Dorong Kemajuan Wirausaha Melalui Pelatihan. Retrieved from http://www.beritasatu.com/advertorial/3605 84-dorong-kemajuan-wirausaha-melaluipelatihan.html

Boyd, B., Fietze, S., \& Philipsen, K. (n.d.). Entrepreneurial Intentions and Behaviour of Students Attending Danish Universities, (06).

Budi Wahyono. (2013). Negara Maju vs Negara Berkembang. Retrieved from http://www.pendidikanekonomi.com/2013/ 08/negara-maju-vs-negaraberkembang.html

Carsrud, A. L., \& Brännback, M. (2009). Understanding the entrepreneurial mind [electronic resource]: opening the black box / Alan L. Carsrud, Malin Brännback, editors. International studies in entrepreneurship: 24. Retrieved from http://0-

search.ebscohost.com.millenium.itesm.mx/l ogin.aspx?direct $=$ true $\& d b=$ cat00524a $\& A N$ =btm.b1287657\&lang=es\&site=edslivelnhttp://rave.ohiolink.edu/ebooks/ebc/97 81441904430

Darmanto, S. (2013). Pengaruh Perceived Desirability,Perceived Feasibility, Propensity To Act Terhadap Intensi Berwirausaha, 1(2).

Dissanayake, D. (2014). The Impact of Perceived Desirability and Perceived Feasibility on Entrepreneurial Intention among 
Undergraduate Students in Sri Lanka: An Extended Model. Kelaniya Journal of Management, $\quad 2, \quad 39-57$. http://doi.org/10.4038/kjm.v2i1.6543

Drennan, J., \& Kennedy, J. (2004). Impact of childhood experiences on the development of entrepreneurial intentions. Entrepreneurship as the Way of the Future, 6(September), 26-29. Retrieved from http://www.ingentaconnect.com/content/ip/i je/2005/00000006/00000004/art00002

Fatoki, O. O. (2010). Graduate entrepreneurial intention in South Africa: motivations and obstacles. International Journal of Business and Management, 5(9), 87-98.

Fitzsimmons, J. R., \& Douglas, E. J. (2011). Interaction between feasibility and desirability in the formation of entrepreneurial intentions. Journal of Business Venturing, 26(4), 431-440. http://doi.org/10.1016/j.jbusvent.2010.01.00 1

Giagtzi, Z. (2013). How perceived feasibility and desirability of entrepreneurship influence entrepreneurial intentions: A comparison between southern and northern European countries, 1-52.

Guerrero, M., Rialp, J., \& Urbano, D. (2008). The impact of desirability and feasibility on entrepreneurial intentions: A structural equation model. International Entrepreneurship and Management Journal, 4(1), 35-50. http://doi.org/10.1007/s11365-006-0032-x

Kritikos, A. (2014). Entrepreneurs and their impact on jobs and economic growth. IZA World of Labor, (May), 1-10. http://doi.org/10.15185/izawol.8

Krueger Jr., N. F., Reilly, M. D., Carsrud, A. L., Krueger, N. F., Reilly, M. D., \& Carsrud, A. L. (2000). Competing models of entrepreneurial intentions. Journal of Business Venturing, 15(5-6), 411-432. http://doi.org/http://dx.doi.org/10.1016/S08 83-9026(98)00033-0

Krueger, J. N. F., \& Carsrud, A. L. (1993). Entrepreneurial intentions: Applying the theory of planned behaviour. Entrepreneurship \& Regional Development, 5(4), 315-330. http://doi.org/10.1080/08985629300000020

Krueger, N. F., Reilly, M. D., \& Carsrud, A. L. (2000). Competing models of entrepreneurial intentions. Journal of Business Venturing, 15(5-6), 411-432. http://doi.org/10.1016/S08839026(98)00033-0

Mair, J., \& Noboa, E. (2005). How intentions to create a social venture are formed: a case study., 3(593), 1-29.

National Association of Colleges and Employers. (2013). College Students Are Attracted to Federal Service, but Agencies Need to Capitalize on Their Interest. National Association of Colleges and Employers. http://doi.org/10.1007/s13398-014-0173-7.2

Nedeljkovic, V. (2014). Consequences of high youth Unemployment. UE ELECTION 2014 , http://doi.org/10.1017/CBO9781107415324 .004

Ngugi, J. K., Gakure, R. W., Waithaka, S. M., \& Kiwara, A. N. (2012). Application of Shapero's Model in Explaining Entrepreneurial Intentions among University Students in Kenya. International Journal of Business and Social Research, 2(4), 125-148. Retrieved from http://www.ijbsr.org/images/archive_article s/August2012/9.pdf

Ratsimanetrimanana, F. A. (2014). The influence of cultural dimensions on entrepreneurial intention in Madagascar' $s$ rural areas.

Robert Hisrich , Michael Peters, D. S. (2008). Entrepreneurship (internatio). Singapore: McGraw-Hill.

Scherer, R. F., Adams, J. S., Carley, S. S., Wiebe, F. A., \& Scherer, R. F., Adams, J. S., Carley, S., \& Wiebe, F. A. (1989). Role model performance effects on development of entrepreneurial career preference. Entrepreneurship Theory and Practice, 13(3), 53-71.

Segal, G., Borgia, D., \& Schoenfeld, J. (2005). The motivation to become an entrepreneur. International Journal of Entrepreneurial Behavior \& Research, 11(1), 42-57. http://doi.org/10.1108/13552550510580834

Shapero, A., \& Sokol, L. (1982). Social dimensions of entrepreneurship. The Encyclopedia of Entrepreneurship, 7240, 72-90. http://doi.org/10.2139/ssrn.1497759

Smith, D. (2010). The role of entrepreneurship in economic growth. Undergraduate Economic Review, 6(1), Article 7.

Solesvik, M., Westhead, P. Kolvereid, L., and Matlay, H. (2012). Student intentions to become self-employed: the Ukrainian context. Journal of Small Business and Enterprise Development, 19(3), 441-460. http://doi.org/10.1017/CBO9781107415324 .004

Summers, D. F. (2000). The formation of entrepreneurial events. Garland Publishing. New york. http://doi.org/10.1017/CBO9781107415324 .004

Timmons, J. A., \& Spinelli, S. (2009). New 
Venture Creation: Entrepreneurship for the 21 st Century. Business. Retrieved from http://www.amazon.com/dp/0071276327

Wang, W., Lu, W., \& Millington, J. K. (2011). Determinants of Entrepreneurial Intention among College Students in China and USA. Journal of Global Entrepreneurship Research, 1(1), 35-44. http://doi.org/10.5430/ijhe.v3n4p106

Weber, R. (2012). Evaluating Entrepreneurship Education. Compendium of continuing education in dentistry (Jamesburg, N.J. : 1995) (Vol. 26). Berlin: Springer. http://doi.org/10.1007/978-3-8349-3654-7

Weerakoon, \& Hhaj, G. (2014). Antecedents of Entrepreneurial Intention, 4(11), 1-6.

Yaseen, A. (1994). Promoting entrepreneurship in the Pakistan, s dairy industry: An empirical testing of two predictive models of entrepreneurial intentions. 